\title{
Self-Healing Concrete Mix-Design Based on Engineered Cementitious Composites Principles ${ }^{\dagger}$
}

\author{
Tudor Panfil Toader ${ }^{1,2, *}$ and Anamaria Cătălina Mircea ${ }^{2}$ \\ 1 NIRD URBAN-INCERC Cluj-Napoca Branch, 117 CaleaFlorești, 400524 Cluj-Napoca, Romania \\ 2 Faculty of Civil Engineering, Technical University of Cluj-Napoca, 15 Constantin Daicoviciu Street, \\ 400020 Cluj-Napoca, Romania; anamaria.mircea@incerc-cluj.ro \\ * Correspondence: tudor.toader@incerc-cluj.ro \\ + Presented at the 14th International Conference on Interdisciplinarity in Engineering-INTER-ENG 2020, \\ Târgu Mureș, Romania, 8-9 October 2020.
}

Published: 10 December 2020

check for

\begin{abstract}
Concrete is the most used material in the construction industry, being prone to cracking. Following the action of aggressive external agents, through cracks, access routes to the embedded reinforcement are created. By enclosing in concrete various materials that can induce the self-healing property, by taking actions when the cracks appear, the access of the external aggressive agents to the reinforcement can be stopped, therefore creating more durable materials. The aim of the research is to design a micro concrete with self-healing properties, based on Engineered Cementitious Composites principles from the literature and using local raw materials.
\end{abstract}

Keywords: micro concrete; self-healing; innovative materials; sustainable development; waste management

\section{Introduction}

Concrete is currently the most used material for in the civil engineering field. Depending on the type of the element and the desired and designed strength, concrete can be used in three different forms: simple concrete, reinforced concrete and reinforced/precompressed concrete. As a porous material, prone to microcracking/cracking, the retrieve of tensile efforts by the concrete are most of the time neglected, having very good properties in retrieving compression efforts, giving rigidity to the structure, and protecting the reinforcement. The retrieve of tensile efforts from the concrete sections is carried out by the reinforcement embedded in the concrete mass [1].

Cracking/microcracking of concrete does not implicitly lead to the failure of the infrastructure/ suprastructure of the buildings of which it belongs, but leads to the formation of pathways for aggressive factors from the external environment, to the reinforcement embedded in the concrete, which in time lead to the decrease in the capacity of the reinforcement to retrieve the tensile efforts of the concrete sections, due to its possible corrosion [2]. Without blocking the access routes of external aggressive factors, structural failure can occur by the loss of the bearing capacity of the elements.

Literature highlights several of the main parameters that can generate the self-healing mechanism of concrete [3], namely:

- Subsequent hydration of un-activated cement in concrete mass;

- Filling cracks due to the action of outside water by transporting particles inside the cracks;

- Formation of calcium carbonate or calcium hydroxide;

- Extension of the hydrated cement matrix into the crack. 
The application of the embedded microcapsule approach as a self-healing agent has been carried out and demonstrated by Withe et al. [4]. When the crack reaches and breaks the embedded microcapsules, the healing agent is released into the cracks through the phenomenon of capillary (Figures 1 and 2). Then the self-healing agent comes into contact with the built-in catalyst, triggering the polymerization reaction and as a result closing the cracks nearby.

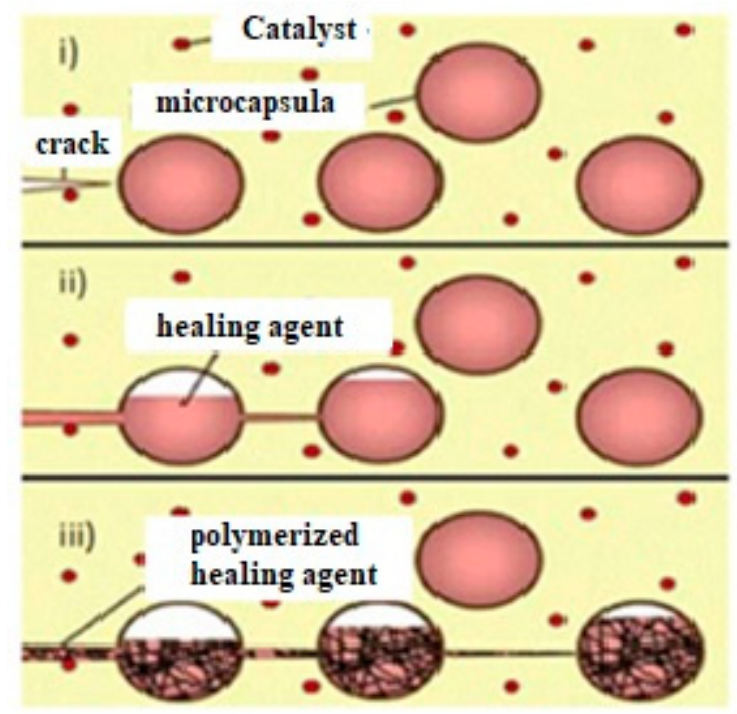

Figure 1. Basic method of approaching microcapsules: (i) formed in the matrix; (ii) crack breaks the microcapsules, releasing the healing agent into the plane of the fissure by capillary action; (iii) the healing agent comes into contact with the catalyst, triggering polymerization thus ensuring the closure of the close cracks [4].

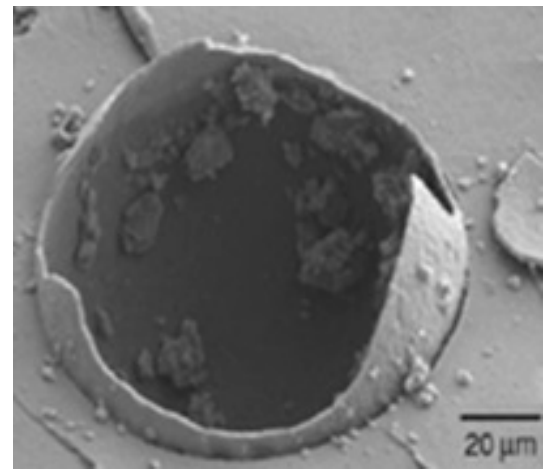

Figure 2. Expansion agents and mineral mixtures_eSEM image showing a broken microcapsule [4].

In another study [5], a geo material with $\mathrm{SiO}_{2}$ content of $71.3 \%$ and an $\mathrm{Al}_{2} \mathrm{O}_{3}$ content of $15.4 \%$ was added together with the expansive agent. Geopolymers were found to be formed by polymerization of individual species of alumina and silicate, which were dissolved from their original sources at high $\mathrm{pH}$ in the presence of alkaline metals. Detailed studies showed that the size of the geopolymeric gel was less than $2 \mu \mathrm{m}$ and that the interface phases of the cracks of the initial cracking area formed several phases of hydrogarnet. It indicated that the phases of hydrogarnates or phases AFt, (Figure 3) were formed of an expansive agent and therefore played an important role in the cracked materials. The EDS analysis also showed that most of the modified geopolymeric gel was structured by dense phases compared to the hydrogarnate phases. Chemical admixtures have also been studied in this research series [5,6]. It was concluded that the addition of carbonates such as $\mathrm{NaHCO}_{3}, \mathrm{Na}_{2} \mathrm{CO}_{3}$ and $\mathrm{Li}_{2} \mathrm{CO}_{3}$ to normal concrete contributed to increased recrystallization of cementitious particles and 
precipitated particles into concrete. In particular, when using the appropriate dosages of carbonates and the expansive agent, the self-healing capacity of the cracks could be improved.

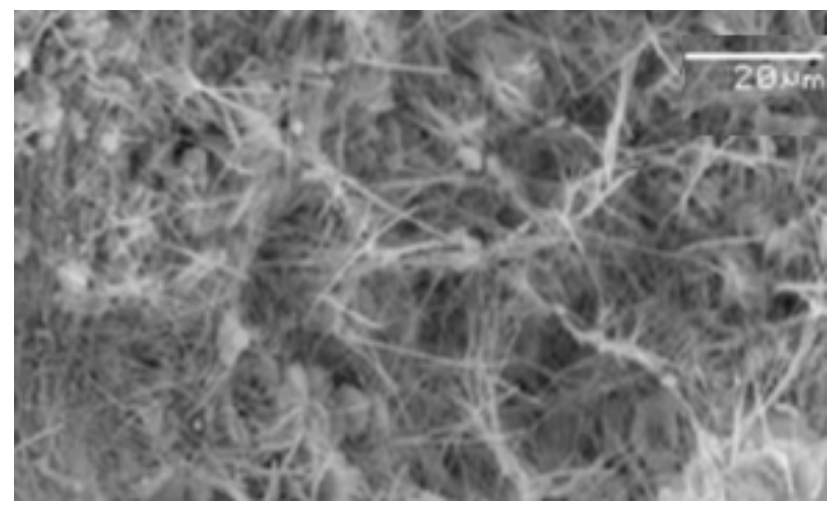

Figure 3. Microscopic image of healing products—formation of hydrogarnet phases [6].

Microbial precipitation of calcium carbonate $\left(\mathrm{CaCO}_{3}\right)$ is determined by factors that include the concentration of inorganic carbon dissolved, the concentration of calcium ions and the presence of nucleic shales. The first three of these factors are veneered by the metabolism of bacteria while cell walls of bacteria action as nuclear sites [7].

Since the cell wall of bacteria is negatively charged, bacteria are able to extract cations from the environment, including positively charged calcium ions, which are deposited on the surface of the cell wall. With this method that induces bacterial precipitation of $\mathrm{CaCO}_{3}$ localized, cracked faces could be filled. Scenario of the process of self-healing of cracks by bacteria immobilized in concrete is illustrated in Figure 4 .
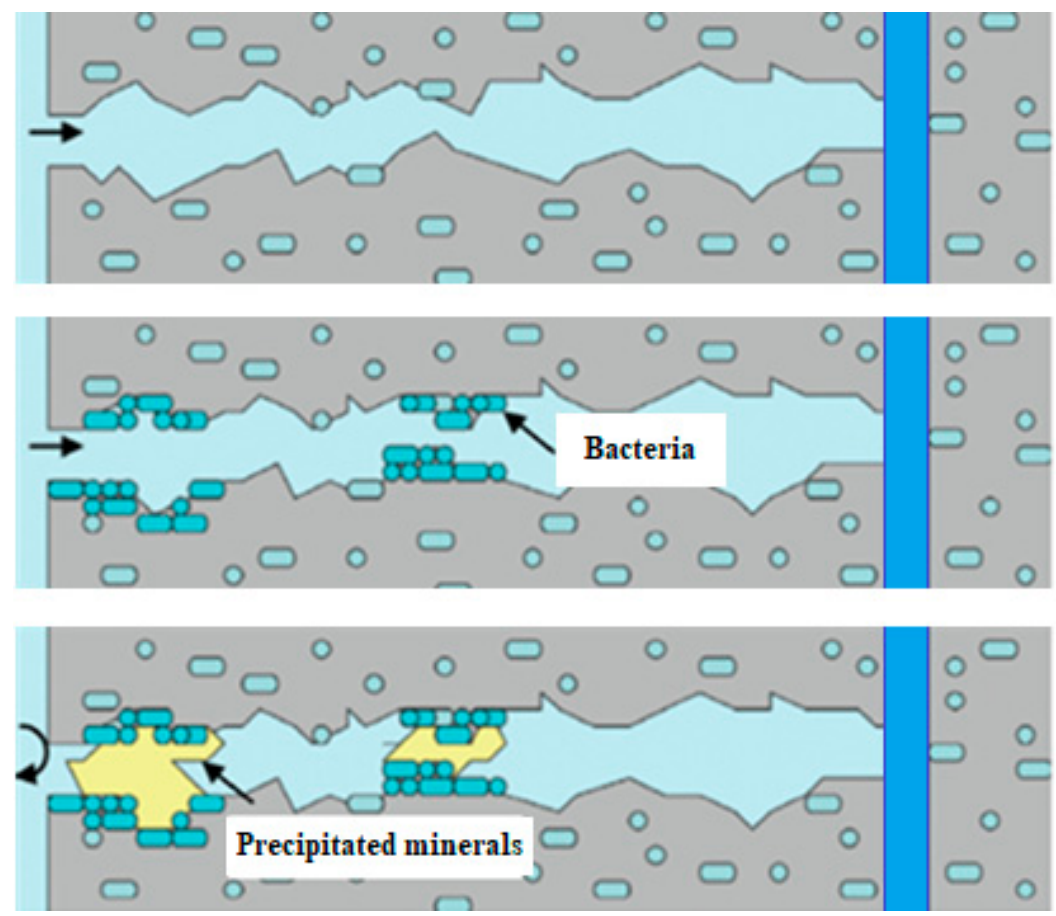

Figure 4. Schematic scenario of healing cracks by bacteria immobilized in concrete. Bacteria on the fresh surface of the fissure become activated due to water ingestion, begin to multiply and precipitate minerals such as calcite, seal the crack and protect the steel reinforcement from external chemical attack [8].

Self-healing concrete could solve the problem of concrete structures deteriorating well before the end of their service life. The success of a knowledge-based society depends on the interaction with the 
business environment and the sources available in order to generate new products and processes [9] Besides the production of materials with self-healing properties, the use of materials derived from industrial by-products, is constantly increasing, therefore demand for special concrete is also increasing (i.e., geopolymer concrete, self-healing concrete) [10,11].

The aim of this research is present preliminary results regarding the mix-design of a new, innovative material, namely micro concrete, with self-healing properties, by using local sources materials (fly-ash, limestone slurry, fibers and aggregates), some of them being considered wastes after several industrial processes.

\section{Materials and Methods}

The design of the micro concrete with self-healing properties is based on the results obtained in the literature on cementitious composite materials, namely on their self-healing property [12]. For the first stage of the study, a micro concrete was designed, by replacing the type of sand used in the production of cementitious composite materials. Two mixtures were studied in which the silica sand with a maximum size of $0.3 \mathrm{~mm}$ used in previous studies [13] was replaced with CEN-Standard Sand (Mixture T1) and with river sand (Mixture T2).

The design of the materials studied in this paper started from the design studied in the literature about Engineered Cementitious Composites [11] and by using the following materials: Portland cement: CEM $42.5 \mathrm{R}$, fly-ash, sand, polymeric PVA fibers (with a density of $1300 \mathrm{~kg} / \mathrm{m}^{3}$ and $8 \mathrm{~mm}$ length), slurry paste and a highly water-reducing superplasticizer. The ratios for the mixture T1 and T2 and SS-L-PVA are presented in Tables 1 and 2. It can be seen that by changing the type of the sand, an optimization of the water used in the mix took place. For both mixtures, with washed river sand and with CEN-Standard Sand, the same quantity of water was used.

Table 1. Mixed design ratios of SS-L-PVA- FA/C used as a model from the literature [13].

\begin{tabular}{cccccccc}
\hline Mixtures & CEM $^{2}$ & FA $^{3}$ & Sand & Water & PVA & LS $^{4}$ & Superplasticizer \\
\hline SS-L-PVA- FA/C & 1.00 & 1.20 & 0.76 & 0.65 & $2.0 \%$ & 0.18 & 0.02 \\
\hline \multicolumn{7}{c}{ values reported to cement quantity, ${ }^{2}$ CEM-cement; ${ }^{3}$ FA-fly-ash, ${ }^{4}$ LS-limestone slurry. }
\end{tabular}

Table 2. Mix-design ratios for T1 and T2.

\begin{tabular}{cccccccc}
\hline Mixtures & CEM $^{2}$ & FA $^{3}$ & Sand & Water & PVA & LS $^{4}$ & Superplasticizer \\
\hline $\mathrm{T} 1, \mathrm{~T} 2$ & 1.00 & 1.20 & 0.76 & 0.58 & $2.0 \%$ & 0.22 & 0.02 \\
\hline \multicolumn{7}{c}{ values reported to cement quantity ${ }^{2}$ CEM-cement; ${ }^{3} \mathrm{FA}-\mathrm{fly}-\mathrm{ash},{ }^{4} \mathrm{LS}-$-limestone slurry. }
\end{tabular}

Starting from the initial mixture of Engineered Cementitious Composite from the literature (Table 1), because of the workability of the new mixtures where the type of sand was changed, silica sand (maximum size of $0.3 \mathrm{~mm}$ ) changed with washed river sand (maximum granule of $4 \mathrm{~mm}$ ) and CEN-standard Sand, an optimization of the quantity of water was made, and decreased from $0.65 \%$ (for SS-L-PVA-FA/C) to $0.58 \%$ (for T1 and T2). As well, the quantity of limestone slurry was increased from $0.18 \%$ (for SS-L-PVA-FA/C) to $0.22 \%$ (for T1 and T2) in the mixtures.

The raw materials used in the production of the concrete were pre-conditioned in laboratory conditions at $(20 \pm 2)^{\circ} \mathrm{C}$ and $(50 \pm 3) \%$ relative humidity and the two types sand were also conditioned until constant mass.

In order to obtain the desired self-healing properties, the ratios in which the materials were used, was carefully monitored in terms of mix-design of the new material. In addition, in the design of the micro concrete, the mixing sequences used for the preparation of the engineered cementitious composites were based on relevant studies in the literature [14]. Two types of mixtures were tested: Mixture T1- with CEN-Standard Sand and Mixture T2 - with river sand with maximum size of $4 \mathrm{~mm}$ (Figure 5).

Tests regarding the mechanical properties of the material were performed at 28 days, on $40 \times 40 \times 160 \mathrm{~mm}$ samples to obtain flexural and $1600 \mathrm{~mm}^{2}$ samples for compressive strength (Figure 6). 


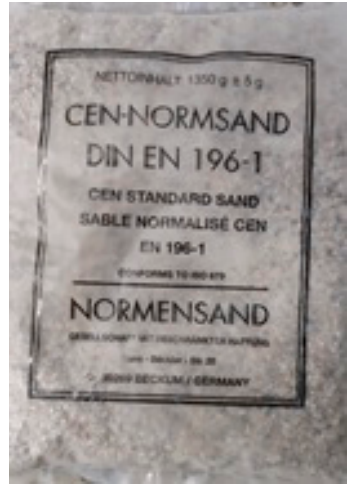

(a)

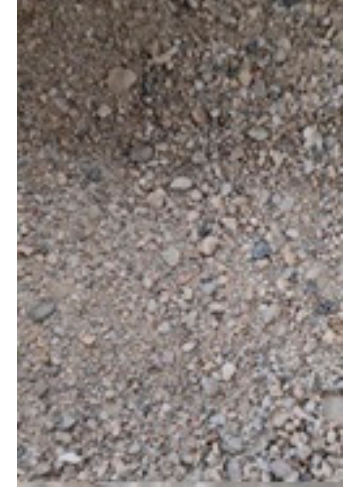

(b)

Figure 5. Sand used in the mixtures: (a) T1-CEN-standard Sand; (b) T2-River sand.

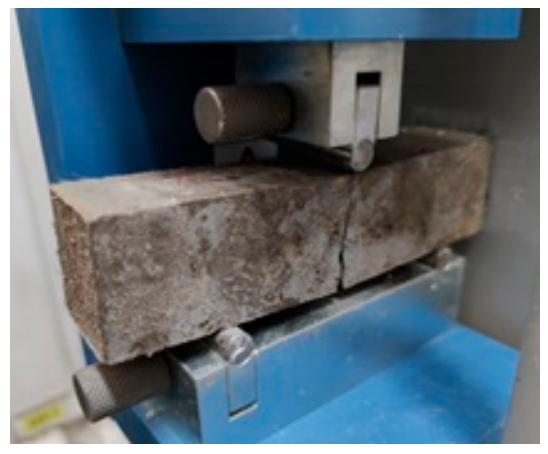

(a)

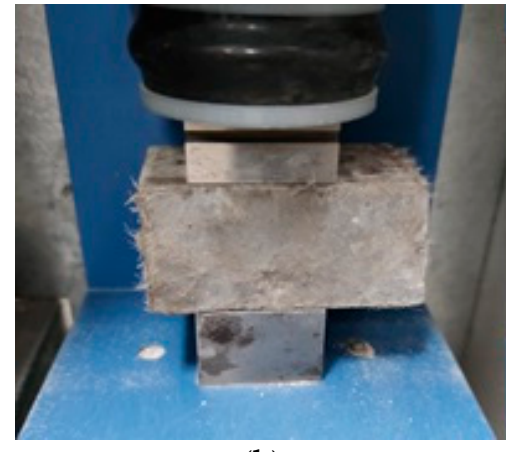

(b)

Figure 6. Mechanical parameters of the mixtures: (a) 3PB test; (b) compressive strength.

Three specimens were cut in halves and tested for the evaluation of the microcracks (Figure 7). To evaluate the self-healing capacity of the micro-concrete, the specimens after being tested were microscopically analyzed using a LEICA DMC 290 Microscope. The specimens after being tested [15] at 28 days were microscopically evaluated with measuring the microcracks and were subjected to 28 cycles of wet/dry. The wet/dry cycles were $12 \mathrm{~h}$ immersed in water and $12 \mathrm{~h}$ in air in laboratory conditions $\left((20 \pm 2){ }^{\circ} \mathrm{C}\right.$ and $\left.(50 \pm 3) \% \mathrm{RH}\right)$ and after 28 days were microscopically reanalyzed. The microcracks width was measured before and after the conditioning of the specimens in order to evaluate the self-healing capacity.

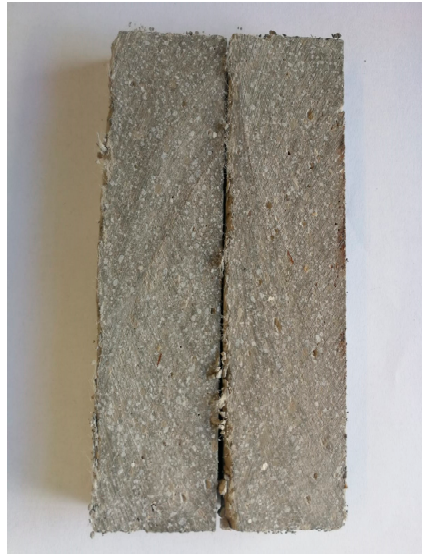

(a)

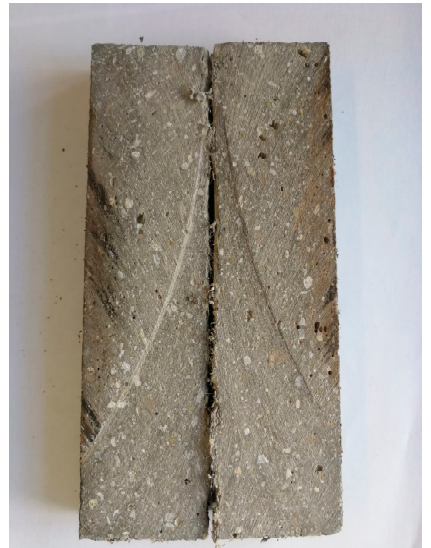

(b)

Figure 7. 3PB section samples for self-healing preparation: (a) T1; (b) T2. 
Figure 8 represents microscopic images of the prismatic specimens made according to recipes T1 and $\mathrm{T} 2$.

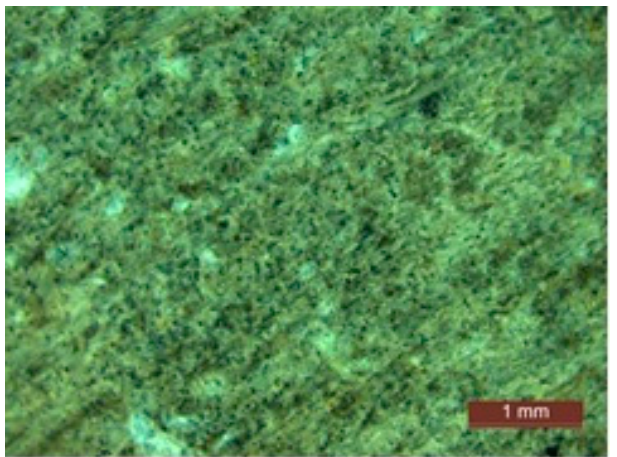

(a)

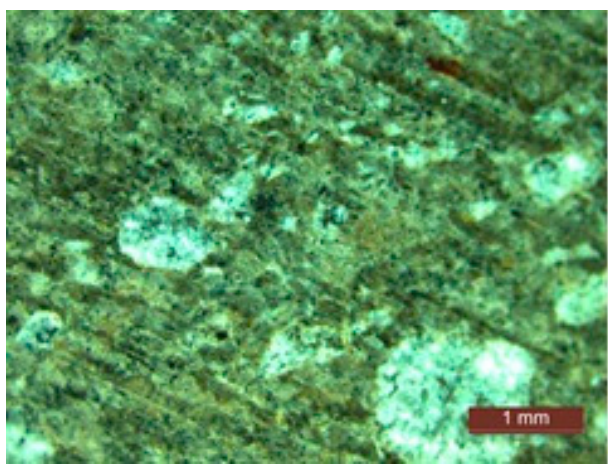

(b)

Figure 8. 3PB section samples microscopical analysis at 28 days: (a) T1; (b) T2.

\section{Results and Discussions}

The mechanical properties of the samples and the initial cracking analyses were carried on at 28 days after being conditioned in water at $(20 \pm 2){ }^{\circ} \mathrm{C}$. Result obtained on the flexural and compressive strength of Mixtures T1 (CEN-Standard Sand) and T2 (River sand) are presented in Table 3.

Table 3. Mechanical properties of the mixtures.

\begin{tabular}{ccc}
\hline Mixture ID & Compressive Strength (MPa) & Flexural Strength (MPa) \\
\hline T1 & 51.2 & 17.2 \\
T2 & 51.3 & 18.1 \\
\hline
\end{tabular}

Test results show that both the flexural strength and the compressive strength of the micro-concrete mixtures are not significantly influenced by the type of the sand used in the production of the samples, with less than $1 \%$ differences in the compressive strength.

The self-healing capacity of the samples was also tested by subjecting the samples presented in Figure 7 to a 3 PB test in order to generate cracks on the surface of the samples, after which the samples were microscopically analyzed. After that, the samples were subjected to 28 wet/dry cycles ( $12 \mathrm{~h}$ immersed in water/12 $\mathrm{h}$ in air) and resubjected to microscopical analysis (Figures 9 and 10). Consequently, for all the samples, at each stage, the mean width of the microcracks $\left(\mathrm{w}_{\text {med }}\right)$ was measured as a parameter of the self-healing capacity (Table 4).

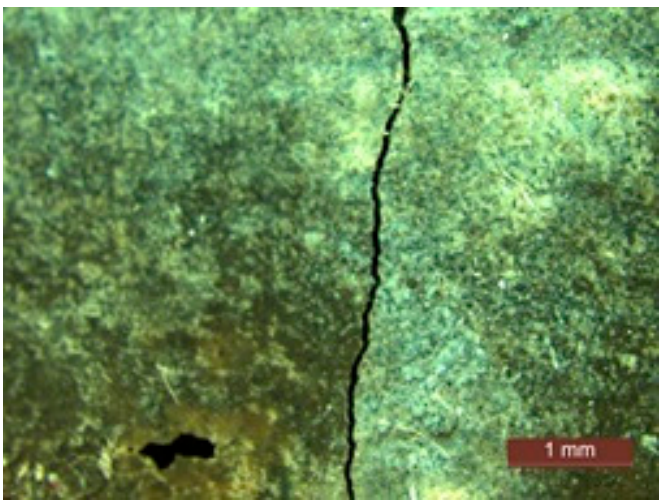

(a)

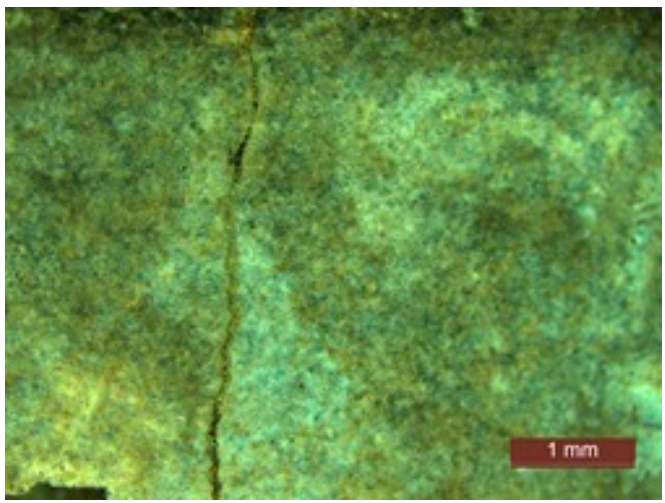

(b)

Figure 9. T1 microcrack evaluation: (a) 28 days initial evaluation; (b) evaluation after 28 wet/dry cycles. 


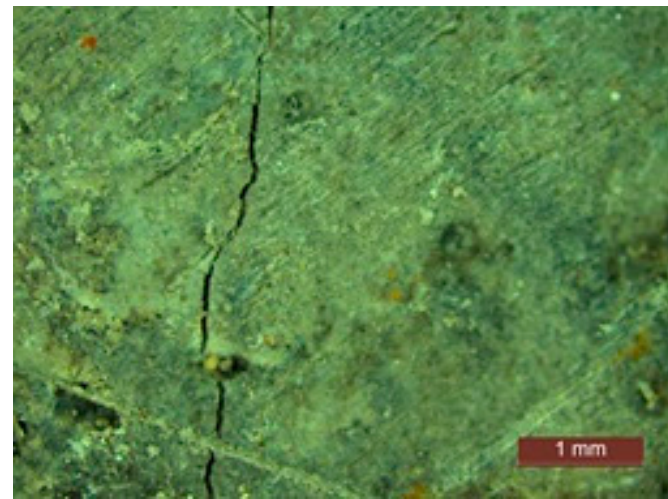

(a)

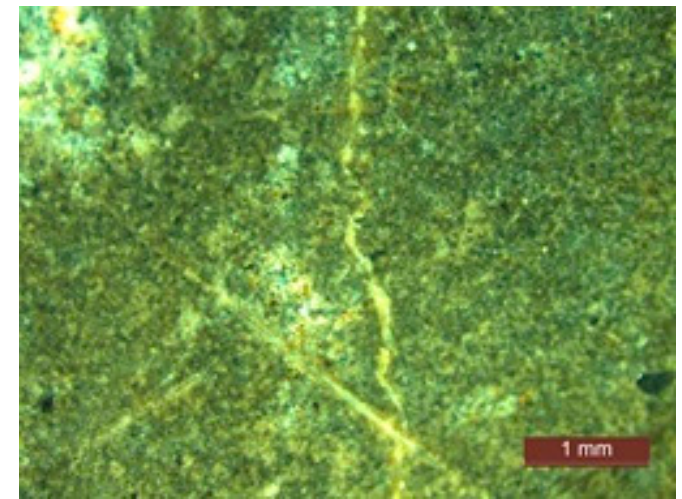

(b)

Figure 10. T2 microcrack evaluation: (a) 28 days initial evaluation; (b) evaluation after 28 wet/dry cycles.

Table 4. Evaluation of the microcracks for T1 and T2 at 28 days and after 28 wet/dry cycles.

\begin{tabular}{cccc}
\hline \multirow{2}{*}{ Mixture ID } & \multicolumn{3}{c}{ Mirocracks Width $(\mu \mathrm{m})$} \\
\cline { 2 - 4 } & $\begin{array}{c}\mathbf{w}_{\text {med }} \\
\text { 28 Days }\end{array}$ & $\begin{array}{c}\mathbf{w}_{\text {med }} \\
\text { after 28 Cycles }\end{array}$ & Microcracks Healing (\%) \\
\hline T1 & 48 & 6 & 80 \\
T2 & 44 & 5 & 88 \\
\hline
\end{tabular}

Results shown in Table 4 and Figures 9 and 10 show that the analyzed microcracks presented a self-healing potential, after being subjected to 28 wet/dry cycles with potential closing of the crack exceeding $80 \%$, for the analyzed cases.

\section{Conclusions}

As fly-ash and limestone slurry are considered by-products form their specific industrial processes and pollutants of the surrounding environment, using them in the production of new, innovative materials could become an important step in the production of sustainable materials for the construction industry.

Based on the above presented test results for compressive and flexural strength, the type of sand used in the mixtures did not significantly influence the mechanical properties of the material.

When comparing the results regarding the self-healing phenomenon with the ones presented in the literature, the microcracks self-healing potential exceeded $80 \%$ for the mixtures designed and studied in this paper and $90 \%$ for the mixtures from the literature.

Current results regarding both the mechanical properties of the analyzed material and the possible self-healing property opens new perspectives regarding the use of local raw materials in order to develop these types of materials. Future studies focus on the optimization of the mixtures, by using other types of fibers (mainly local), developing a mix-design by using larger size aggregates and by using new types of admixtures in order to study the possibility of producing micro-concrete with self-healing properties.

Author Contributions: Conceptualization, T.P.T. and A.C.M.; methodology, T.P.T. and A.C.M.; validation, T.P.T. and A.C.M.; formal analysis, T.P.T.; investigation, T.P.T.; data curation, T.P.T.; writing-original draft preparation, T.P.T.; writing-review and editing, T.P.T. and A.C.M.; supervision, T.P.T. All authors have read and agreed to the published version of the manuscript.

Funding: This research received no external funding.

Conflicts of Interest: The authors declare no conflict of interest. 


\section{References}

1. Wu, M.; Johannesson, B.; Geiker, M. A review: Self-healing in cementitious materials and engineered cementitious composite as a self-healing material. Constr. Build. Mater. 2012, 28, 571-583. [CrossRef]

2. Mircea, A.C.; Toader, T.P. Self-healing concrete. Sci. B Adv. 2020, 5, 324-337.

3. Li, V.C.; Herbert, E. Robust Self- Healing Concrete for Sustainable Infrastructure. J. Adv. Concr. Technol. 2012, 10, 207-218. [CrossRef]

4. White, S.R.; Sottos, N.R.; Geubelle, P.H.; Moore, J.S.; Kessler, M.R.; Sriram, S.R. Autonomic healing of polymer composites. Nature 2001, 409, 794-797. [CrossRef]

5. Ahn, T.H.; Kishi, T. The effect of geomaterials on the autogenous healing behavior of cracked concrete. In Concrete Repair, Rehabilitation and Retrofitting II: 2nd International Conference on Concrete Repair, Rehabilitation and Retrofitting, ICCRRR-2, 24-26 November 2008, Cape Town, South Africa; CRC Press: Cambridge, UK, 2008; pp. 235-240.

6. Ahn, T.H.; Kishi, T. Crack self-healing behavior of cementitious composites incorporating various miner admixtures. J. Adv. Concr. Technol. 2010, 8, 171-186. [CrossRef]

7. Tittelboom, K.V.; De Belie, N.; Muynck, W.D.; Verstraete, W. Use of bacteria to repair cracks in concrete. Cem. Concr. Res. 2010, 40, 157-166. [CrossRef]

8. Jonkers, H.M.; Thijssen, A.; Muyzer, G.; Copuroglu, O.; Schlangen, E. Application of Bacteria As Self-Healing Agent for the Development of Sustainable Concrete. In Proceedings of the 1st International Conference on BioGeoCivil Engineering-Delft, Delft, The Netherland, 23-25 June 2008.

9. Rus, M.-I. The Knowledge Triangle in a Knowledge-Based Society; Annals of Faculty of Economics, University of Oradea, Faculty of Economics: Oradea, Romania, 2013; Volume 1, pp. 942-947.

10. Lăzărescu, A.; Szilagyi, H.; Baeră, C.; Hegyi, A.; Meiţă, V. Experimental Investigation on the Development of Geopolymer Paving Blocks by Using Romanian Local Raw Materials. IOP Conf. Ser.: Mater. Sci. Eng. 2020, 877, 012034. [CrossRef]

11. Hegyi, A.; Szilagyi, H.; Grebenişan, E.; Sandu, A.V.; Lăzărescu, A.-V.; Romila, C. Influence of $\mathrm{TiO}_{2} \mathrm{Nanoparticles}$ Addition on the Hydrophilicity of Cementitious Composites Surfaces. Appl. Sci. 2020, 10, 4501. [CrossRef]

12. Piscoiu, D.N.; Mircea, A.C.; Toader, T.P. Engineered composites materials a new sustainable approach. Sci. B. Adv. 2020, 5, 345-348.

13. Mircea, A.C.; Mircea, C.; Szilágyi, H.; Baeră, C.; Hegyi, A. Experimental study regarding the influence of fibre to matrix compatibility on general performance of Fibre Engineered Cementitious Materials (FECM). MATEC Web Conf. 2019, 289, 04005. [CrossRef]

14. Snoeck, D.; Dewanckele, J.; Cnudde, V.; De Belie, N. X-ray computed microtomography to study autogenous healing of cementitious materials promoted by superabsorbent polymers. Cem. Concr. Compos. 2016, 65, 83-93. [CrossRef]

15. ASRO. SR EN 196-1 Methods of Testing Cement. Determination of Strength; Romanian Standards Association: Bucharest, Romania, 2016.

Publisher's Note: MDPI stays neutral with regard to jurisdictional claims in published maps and institutional affiliations.

(C) 2020 by the authors. Licensee MDPI, Basel, Switzerland. This article is an open access article distributed under the terms and conditions of the Creative Commons Attribution (CC BY) license (http://creativecommons.org/licenses/by/4.0/). 